\title{
Pollination effectiveness of European honeybee, Apis mellifera (Hymenoptera: Apidae), in an Oriental persimmon, Diospyros kaki (Ericales: Ebenaceae), orchard
}

\author{
Shoko Nakamura ${ }^{1} \cdot$ Shunsuke Yamamoto $^{2} \cdot$ Nobuo Sawamura $^{2} \cdot$ Aoi Nikkeshi $^{3} \cdot$ Shigeki Kishi $^{4} \cdot$ Tsunashi Kamo $^{3}$
}

Received: 22 April 2020 / Accepted: 20 August 2020 / Published online: 5 September 2020

(c) The Author(s) 2020

\begin{abstract}
Most common cultivars of Oriental (or Japanese) persimmon, Diospyros kaki Thunb. (Ericales: Ebenaceae), set mostly female flowers and require pollen from male flowers of other cultivars for pollination. Growers often introduce the European honeybee, Apis mellifera L. (Hymenoptera: Apidae), into their orchards to promote pollination. Here, we investigated the pollination effectiveness of A. mellifera for $D$. kaki 'Saijo,' by monitoring flower visitors, analyzing pollen grains on bees' body surfaces, and comparing the number of mature seeds in fruits among years with different pollinator availabilities. Apis mellifera and the bumblebee Bombus ardens ardens Smith (Hymenoptera: Apidae) were the major visitors for 3 years, although their dominance varied among years. The number of mature seeds was positively correlated with the number of $B$. ardens ardens visiting $D$. kaki flowers, but not with that of A. mellifera. Apis mellifera might be less efficient because visitors to female flowers carried significantly fewer pollen grains on their body surfaces than those of $B$. ardens ardens. Analysis of pollen loads of honeybees captured at their nest entrance suggested their preference for red clover, Trifolium pratense $\mathrm{L}$. (Fabales: Fabaceae), and Toxicodendron spp. (Sapindales: Anacardiaceae), over D. kaki as a pollen source in our study site. The effectiveness of A. mellifera on D. kaki pollination should be carefully evaluated considering the effects of coexisting floral and pollinator species.
\end{abstract}

Keywords Apis mellifera $\cdot$ Bombus ardens ardens $\cdot$ Diospyros kaki $\cdot$ Flower visitation $\cdot$ Pollen $\cdot$ Trifolium pratense

Electronic supplementary material The online version of this article (https://doi.org/10.1007/s13355-020-00696-5) contains supplementary material, which is available to authorized users.

Tsunashi Kamo

tkamo@affrc.go.jp

1 Forestry and Forest Products Research Institute, Forest Research and Management Organization, 1 Matsunosato, Tsukuba, Ibaraki 305-8687, Japan

2 Shimane Agricultural Technology Center, 2440 Ashiwata, Izumo, Shimane 693-0035, Japan

3 Institute for Agro-Environmental Sciences, National Agriculture and Food Research Organization, 3-1-3 Kannondai, Tsukuba, Ibaraki 305-8604, Japan

4 Research Center for Agricultural Information Technology, National Agriculture and Food Research Organization, Kintetsu Kasumigaseki Building, 3-5-1 Kasumigaseki, Chiyoda-ku, Tokyo 100-0013, Japan

\section{Introduction}

The Oriental (or Japanese) persimmon, Diospyros kaki Thunb. (Ericales: Ebenaceae), is a familiar fruit in eastern Asia. This species is generally diclinous, but most typical cultivars set mostly female flowers (Yonemori et al. 1992) and require pollen transfer from male flowers of other pollinizer cultivars interplanted with the main cultivars or grafted onto their stems. Although some wild bees have been found as flower visitors (Asami and Chow 1936; Tokunaga et al. 1959; Yokozawa 1951), their pollination effectiveness has been unknown. Nikkeshi et al. (2019) recently revealed that the bumblebee Bombus ardens ardens Smith (Hymenoptera: Apidae) was the most effective wild pollinator of D. kaki in Hiroshima, Japan, by analyzing the number of pollen grains on the body surfaces of visitor species and the visitation frequencies to male and female flowers. However, the availability of wild pollinators would be site dependent, as Nikkeshi et al. (2019) suggested the contribution of surrounding secondary forest. 
When wild pollinators are scarce owing to the poor quality of surrounding habitat, other options are required to ensure pollination. Two major options are used: the introduction of domesticated pollinators (Fukae et al. 1987; Yokozawa et al. 1968) and hand pollination (Kawagoe and Inoue 1958; Ono 1956; Yokozawa 1951). Hives of the European honeybee, Apis mellifera L. (Hymenoptera: Apidae), are commonly introduced into $D$. kaki orchards as needed because this bee is believed to pollinate D. kaki (Yamamura et al. 1989). However, the honeybees contribution might be supported by their mass visitation, not by the efficiency of a single visit (Morse 1991). Fukae et al. (1987) suggested that more than 20 visits by A. mellifera to a female flower might be necessary for seed formation. They reported that 7 day introduction of $A$. mellifera hives into orchards of $D$. kaki 'Fuyu' increased the ratio of seed formation from $36.7 \%$ (negative control) to $67.7 \%$, comparable with that of hand pollination (66.5\%), but the ratio was still $46.5 \%$ after 1 day.

In contrast to the low pollination efficiency of a single visit to D. kaki, A. mellifera heavily visits the flowers to collect pollen and nectar when introduced into an orchard (Fukae et al. 1987). Beekeepers recognize $D$. kaki as an excellent nectar source for honey production (Sasaki 2010). Because female flowers produce nectar and male flowers produce pollen, $A$. mellifera utilizes both sexes of flowers (Sasaki 2010; Yokozawa 1951, 1952). The low pollination efficiency might be due to their few cross-visitations between female and male flowers. Honeybees might exclusively visit one sex of flowers during their bouts, but previous studies lack information (Fukae et al. 1987; Yokozawa 1951, 1952; Yokozawa et al. 1968).

We examined whether introduced $A$. mellifera could be comparable to wild bees as a pollen transporter by comparing flower visitations and the number of pollen grains on the body surfaces between A. mellifera and a major wild pollinator, $B$. ardens ardens. We predicted that the numbers of pollen grains found on A. mellifera workers captured on female flowers should be far smaller than those on male flowers, but those on $B$. ardens ardens should not differ between floral sexes. As more visits by an effective pollinator species would result in more mature seeds in a fruit, we examined whether the number of seeds in a fruit increased with increased visitation by each of the two major visitor species. Finally, we analyzed the pollen loads isolated from homing workers of $A$. mellifera to see whether they foraged pollen of $D$. kaki.

\section{Materials and methods}

\section{Study site}

Field experiments were conducted in an orchard of the Shimane Agricultural Technology Center, Izumo, Japan $\left(35^{\circ} 19.5^{\prime} \mathrm{N}, 132^{\circ} 44.1^{\prime} \mathrm{E}, 33 \mathrm{~m}\right.$ a.s.l.). We selected this site because both $A$. mellifera and $B$. ardens ardens were present here in a preliminary observation. The 10 year mean monthly temperature ranged from $4.7^{\circ} \mathrm{C}$ in January to $26.7^{\circ} \mathrm{C}$ in August $\left(17.5^{\circ} \mathrm{C}\right.$ in May), and the mean annual precipitation was $1739 \mathrm{~mm}$, recorded at a nearby automated meteorological station of the Japan Meteorological Agency $\left(35^{\circ} 19.9^{\prime} \mathrm{N}, 132^{\circ} 43.8^{\prime} \mathrm{E}, 20 \mathrm{~m}\right.$ a.s.l.) from 2009 to 2018 .

The center's orchards, where Oriental persimmon, grape, Japanese chestnut, Japanese pear, and fig grow, are surrounded by rice paddy fields and secondary forests (Fig. S1). They grow 60 D. kaki trees (53 'Saijo,' 6 'Zenjimaru,' 1 'Saefuji') in an area of about $3000 \mathrm{~m}^{2}$. Field experiments used 'Saijo.' This cultivar, grown mainly in the Chugoku district (Japanese Government Statistics 2016), sets mostly female flowers. Owing to its low parthenocarpic ability, seed formation following pollination is important for stable production (Yamamura 1982). 'Zenjimaru' and 'Saefuji' produce many male flowers and are planted as pollinizers in the eastern and western rows. The peak blooming dates (when $80 \%$ of flowers had bloomed) of 'Saijo' were 24 May 2017, 26 May 2018, and 26 May 2019. Both cultivars of pollinizers started flowering earlier and lasted a bit longer than 'Saijo.'

Hives of A. mellifera were placed at the edge of the orchard, one hive from 17 May to 10 June 2017, one from 13 May to 4 June 2018, and two from 17 May to 3 June 2019, covering the blooming season of $D$. kaki. The activity of the introduced hive was evaluated by counting homing and leaving workers for $5 \mathrm{~min}$ in front of the hive eight times a day from 05:00 to 18:30 h on 26, 30, and 31 May 2017. In general, diurnal dynamics of homing workers and leaving workers were similar, having a morning peak and an afternoon peak, when approximately 200 to 500 workers were arriving and leaving within 5 min (Fig. S2). We confirmed that the colonies placed in 2018 and 2019 were as active as that in 2017 , although we did not count the number of foraging workers.

\section{Observation of flower visitors}

To identify major visitors to the flowers of $D$. kaki, we recorded the functional groups of insects that visited the flowers in the orchard in 30-min periods every $2 \mathrm{~h}$ between 05:30 and 18:00 $\mathrm{h}$ on 26, 30, and 31 May 2017 and between 07:00 and 18:00 h on 24, 27, and 28 May of 2018 and 2019. During the survey, two observers walked around the orchard to monitor visitors to female flowers of 'Saijo' and male flowers of 'Zenjimaru,' but floral sexes were not distinguished in 2017. The flower visitors were categorized into six functional groups: bumblebees, carpenter bees, honeybees, other hymenopterans, dipterans, and beetles. 


\section{Identification of insects captured on D. kaki}

We captured some of the flower visitors during the monitoring for species identification (2017-2019) and for the pollen analysis (2019). In 2017, we captured 38 individuals in an insect net. Each insect was placed in a numbered tube with $3-5 \mathrm{~mL}$ of ethanol and stored at room temperature until identification. In 2018, we captured 86 individuals in an insect net or in a $5 \mathrm{~mL}$ vial (or a $50 \mathrm{~mL}$ tube for carpenter bees) pushed over an insect in the bottom of a D. kaki flower. In 2019, we captured 105 individuals in a $5 \mathrm{~mL}$ vial as in 2018. Each vial was immediately put on ice in a cooler bag to quell the insect's activity and to prevent decomposition of the pollen loads. They were then stored at $-30{ }^{\circ} \mathrm{C}$ until pollen-counting and identification in the laboratory. The sex of flowers on which the insects were captured was recorded in 2018 and 2019.

We first morphologically identified all of the captured individuals. To verify the identification, we used DNA barcoding for 14 individuals of the Andrenidae, Cantharidae, Elateridae, Halictidae, Scarabaeidae, Scoliidae, and Syrphidae (Table S1). To amplify a segment of mitochondrial cytochrome $c$ oxidase 1 (CO1), we used primers BarbeeF (forward: 5'-CAACAAATCATAAAAATA TTGG-3'; Françoso and Arias 2013) and MtD9 (reverse: 5'-CCCGGTAAAATTAAAATATAAACTTC-3'; Simon et al. 1994) for the hymenopterans and LCO1490 (forward: 5'-GGTCAACAAATCATAAAGATATTGG-3') and HCO2198 (reverse: 5'-TAAACTTCAGGGTGACCAAAA AATCA-3'; Folmer et al. 1994) for the others. Table S1 describes the DNA extraction, barcode region amplification, sequencing, and molecular identification. The sequences were deposited in the DNA Data Bank of Japan (DDBJ accession numbers LC512836-49). We did not confirm species identification of the bees belonging to the Apidae or the citrus flower chafer Gametis jucunda Faldermann (Coleoptera: Scarabaeidae) by DNA barcoding, because they can be identified accurately by morphology.

\section{Counting pollen grains}

To evaluate potential as a pollen transporter, we counted the Diospyros pollen grains on the body surfaces of individuals of $B$. ardens ardens and A. mellifera captured on male and female flowers of D. kaki in 2019. After cutting away each sample's hind legs with scissors to remove the pollen loads, we counted pollen grains in small drops of $0.4 \mathrm{M}$ sucrose solution containing grains disengaged from the body surface under a microscope (Eclipse E200; Nikon, Tokyo, Japan), as described in detail by Nikkeshi et al. (2019).

\section{Number of mature seeds}

We counted mature seeds in 70 randomly selected fruits harvested on 30 October 2017, 72 on 25 October 2018, and 90 on 1 November 2019. The maximum possible number of seeds formed in a $D$. kaki fruit is eight.

\section{Pollen grains on homing workers of $A$. mellifera}

To reveal floral usage by A. mellifera, we captured 95 homing workers in front of a hive placed in the orchard on 24, 27, and 28 May 2019 (Table S2) and counted the Diospyros pollen grains on their body surfaces as above.

All 19 individuals that held pollen loads on their hind legs were used for the analysis of pollen loads. DNA was extracted from each isolated pollen load with a DNeasy Plant Mini Kit (Qiagen, Valencia, CA, USA). DNA barcoding analysis used the $t r n L$ intron and $t r n L-t r n F$ intergenic spacer of chloroplast DNA ( $t r n L-t r n F)$. To amplify $\operatorname{trn} L-t r n F$, we used primers trnL-c (forward: 5'-CGAAATCGGTAGACG CTACG-3') and trnF-f (reverse: 5'-ATTTGAACTGGTGAC ACGAG-3' Taberlet et al. 1991). The amplification reaction contained $0.08 \mu \mathrm{L}$ of ExTaq polymerase (Takara Bio, Shiga, Japan; $5 \mathrm{U} / \mu \mathrm{L}), 1.6 \mu \mathrm{L}$ of ExTaq buffer $\left(\mathrm{Mg}^{2+}\right.$ free $), 1.3 \mu \mathrm{L}$ of $\mathrm{MgCl}_{2}(25 \mathrm{mM}), 1.3 \mu \mathrm{L}$ of dNTP mixture ( $2.5 \mathrm{mM}$ each), $0.5 \mu \mathrm{L}$ of DNA template, $0.5 \mu \mathrm{L}$ each of forward and reverse primers $(10 \mu \mathrm{M})$, and purified water up to $16.6 \mu \mathrm{L}$. PCR cycles consisted of an initial denaturation step for $4 \mathrm{~min}$ at $94{ }^{\circ} \mathrm{C} ; 35$ cycles of denaturation for $30 \mathrm{~s}$ at $94{ }^{\circ} \mathrm{C}$, annealing for $40 \mathrm{~s}$ at $52{ }^{\circ} \mathrm{C}$, and extension for $1 \mathrm{~min}$ at $72{ }^{\circ} \mathrm{C}$; and a final extension for $10 \mathrm{~min}$ at $72{ }^{\circ} \mathrm{C}$. The PCR products were analyzed by electrophoresis in 2\% (w/v) agarose gel, treated with ExoSAP-IT cleanup reagent (USB Corp., Cleveland, $\mathrm{OH}, \mathrm{USA}$ ), and directly sequenced in both directions in an ABI 3130xl genetic analyzer (Applied Biosystems, Foster City, CA, USA) with a big dye terminator cycle sequencing ready reaction kit (applied biosystems), using the same primers as used for PCR. The amplified sequences were molecularly identified by generating a phylogenetic tree for the sequences obtained, along with species with high levels of identity that were retrieved from the GenBank/NCBI database by BLAST search. All sequences were aligned by CLUSTALW in MEGA7 software (Kumar et al. 2016). Phylogenetic relationships were analyzed by using the maximum likelihood method based on the Tamura-Nei model (Tamura and Nei 1993) in MEGA7. The sequences were deposited in the DDBJ (accession numbers LC512912-30).

\section{Statistical analysis}

To compare the ratios of honeybees and bumblebees among the years, we used Fisher's exact probability test. To compare the numbers of Diospyros pollen grains on the body 
surfaces between $B$. ardens ardens and A. mellifera captured on male and female flowers, we used a generalized linear model (GLM) in which the estimated number of pollen grains was the response variable with a negative binomial probability distribution, and flower sex, bee species, and their interaction were explanatory variables. To examine whether the number of mature seeds differed depending on the number of monitored individuals of either species, we first separated the dataset of the seed numbers into two sets by a method of randomization before performing GLMs for $B$. ardens ardens and A. mellifera, respectively, because we found a negative correlation between annual total numbers of visits by B. ardens ardens and A. mellifera (Pearson's $r=-0.98)$ in a preliminary analysis. We then used GLMs in which the number of mature seeds was a response variable with a binomial distribution, the annual total number of monitored individuals of either species was an explanatory variable, and the number of $30 \mathrm{~min}$ monitoring sessions (21 in 2017; 18 in 2018 and 2019) was an offset. All statistical analyses were performed in R v. 3.5.3 software (R Development Core Team 2019).

\section{Results}

\section{Observation of flower visitors}

We monitored 230 individuals in 2017, 360 in 2018, and 244 in 2019. Honeybees and bumblebees were dominant, representing $86.5 \%$ of the total in $2017,79.1 \%$ in 2018 , and $81.1 \%$ in 2019 (Table 1). Of the 604 records during 2018-2019, honeybees accounted for 33 visits to female flowers and 52 to male flowers, and bumblebees accounted for 217 visits to female flowers and 181 to male flowers. The ratios of bumblebees and honeybees differed significantly between years (Fisher's exact test, $P<0.0001$ ): honeybees were the most frequent visitor found on D. kaki flowers in 2017, but bumblebees were the most frequent in 2018 and 2019 (Table 1). Other functional groups (carpenter bees, other hymenopterans, dipterans, and beetles) were minor, accounting for at most $8.6 \%$ (beetles in 2018) of the total numbers. We confirmed bumblebees and honeybees sucking nectar on the female flowers and collecting pollen on the male flowers. In the female flowers, both frequently touched the stigmas with their heads and thoraces (Fig. S3) and often hung onto stigmas when landing on or leaving the flowers (Video 1). They occasionally groomed their body surfaces to form pollen loads just before leaving the male flowers (Video 2).

\section{Identification of insects captured on D. kaki}

All 15 honeybees captured in 2017 and 2018 were identified as A. mellifera (Table S3). Of 33 honeybees captured in 2019, 30 were A. mellifera (90.9\%) and three were the Japanese honeybee, Apis cerana japonica Radoszkowski (Hymenoptera: Apidae) (9.1\%). Almost all of the 104 bumblebees captured between 2017 and 2019 were B. ardens ardens, except for one Bombus ignitus Smith (Hymenoptera: Apidae). Eleven 'other' hymenopterans were identified as Andrena opacifovea Hirashima (Hymenoptera: Andrenidae), Eucera nipponensis (Pérez) (Hymenoptera: Apidae), Lasioglossum mutilum (Vachal), Lasioglossum occidens (Smith) (Hymenoptera: Halictidae), and Campsomeriella annulata (Fabricius) (Hymenoptera: Scoliidae), along with one unidentified (Hymenoptera: Ichneumonidae).

\section{Counting of pollen grains}

The numbers of Diospyros pollen grains counted on the body surfaces of the two bee species averaged $25716 \pm 26158$ (mean \pm S.D.) on B. ardens ardens captured on female flowers $(N=14), 33716 \pm 22130$ on those captured on male flowers $(N=28), 88 \pm 72$ on A. mellifera captured on female flowers $(N=5)$, and $17202 \pm 13081$ on those captured on
Table 1 Numbers of observed flower visitors of Diospyros kaki

\begin{tabular}{|c|c|c|c|c|c|c|c|c|c|c|}
\hline \multirow{2}{*}{$\begin{array}{l}\text { Year } \\
\text { Flower sex }\end{array}$} & \multicolumn{2}{|l|}{$2017^{\mathrm{a}}$} & \multicolumn{4}{|l|}{2018} & \multicolumn{4}{|l|}{2019} \\
\hline & Total & $(\%)$ & Female & Male & Total & $(\%)$ & Female & Male & Total & $(\%)$ \\
\hline Honeybees & 166 & 72.2 & 8 & 9 & 17 & 4.7 & 25 & 43 & 68 & 27.9 \\
\hline Bumblebees & 33 & 14.3 & 166 & 102 & 268 & 74.4 & 51 & 79 & 130 & 53.3 \\
\hline Carpenter bees & 12 & 5.2 & 12 & 10 & 22 & 6.1 & 1 & 19 & 20 & 8.2 \\
\hline Other hymenopterans & 0 & 0.0 & 3 & 0 & 3 & 0.8 & 4 & 4 & 8 & 3.3 \\
\hline Dipterans & 16 & 7.0 & 5 & 14 & 19 & 5.3 & 0 & 2 & 2 & 0.8 \\
\hline Beetles & 3 & 1.3 & 26 & 5 & 31 & 8.6 & 2 & 14 & 16 & 6.6 \\
\hline Total & 230 & 100.0 & 220 & 140 & 360 & 100.0 & 83 & 161 & 244 & 100.0 \\
\hline
\end{tabular}

Insect individuals were recorded for 30 min every $2 \mathrm{~h}$ between 05:30 and 18:00 h for 3 days in 2017 and between 07:00 and 18:00 h for 3 days in 2018 and 2019. Two observers walked around the orchard to monitor visitors to flowers.

${ }^{\mathrm{a}}$ Flower sex was not distinguished in 2017 
male flowers $(N=25)$ (Fig. 1). The GLM detected a significant difference in the numbers of pollen grains between the two species ( $\mathrm{df}=1, Z=-11.47, P<0.0001)$, but not between flower sexes ( $\mathrm{df}=1, Z=0.88, P=0.38)$. It detected a significant effect of the interaction between flower sex and species $(\mathrm{df}=1, Z=8.95, P<0.0001)$. The effect of flower sex on the number of pollen grains on the body surface was larger in A. mellifera (Fig. 1).

\section{Number of mature seeds}

The median numbers of seeds were 2 in 2017 and 3 in 2018 and 2019 (Fig. 2). The numbers of mature seeds were larger in the years with larger visitation by $B$. ardens ardens $(N=116, \mathrm{df}=2, Z=3.92, P<0.001 ;$ Fig. $2 \mathrm{a})$ and smaller in the year with larger visitation by A. mellifera $(N=116$, $\mathrm{df}=2, Z=-3.35, P<0.001$; Fig. $2 b$ ).

\section{Pollen grains on homing workers of $A$. mellifera}

Among the 95 homing A. mellifera workers captured in front of the hive, more than half ( 60 of $95 ; 63.2 \%$ ) had $<200$ Diospyros pollen grains on the body surface, but five individuals $(5.2 \%)$ had $>10000$ grains $(<27780)$ (Fig. S4).

One-fifth of individuals (19 of 95) had pollen loads on their hind legs (Table S2). Ten of the pollen loads were

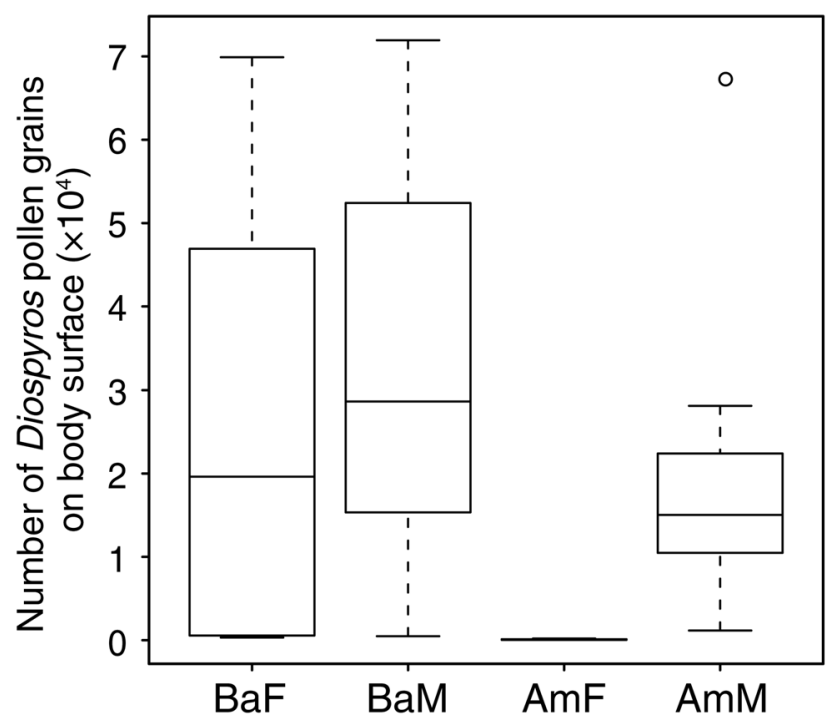

Fig. 1 Numbers of Diospyros pollen grains on the body surface of flower visitors to D. kaki. BaF: Bombus ardens ardens on female flowers $(N=14)$; BaM: $B$. ardens ardens on male flowers $(N=28)$; AmF: Apis mellifera on female flowers $(N=5)$; AmM: A. mellifera on male flowers $(N=25)$. The top and bottom lines of the boxes indicate upper and lower quartiles, horizontal lines inside the boxes indicate median, top and bottom ends of whiskers indicate 1.5-interquartile ranges (IQR) between lower (25th percentile-1.5.IQR) and upper (75th percentile $+1.5 \cdot \mathrm{IQR})$ values, and circle represents outliers identified as red clover, Trifolium pratense L. (Fabales: Fabaceae) (Fig. S5). Of the rest, seven were Toxicodendron spp., one white clover, Trifolium repens L. (Fabales: Fabaceae), and one buckwheat, Fagopyrum esculentum Moench (Caryophyllales: Polygonaceae). No D. kaki pollen load was detected. The five individuals that had abundant Diospyros pollen on their body surfaces did not convey pollen loads.

\section{Discussion}

At our study site, B. ardens ardens and A. mellifera were the major visitors to $D$. kaki flowers. However, their contributions to the pollination might differ. While visitations by $B$. ardens ardens were positively related to the seed formation of $D$. kaki, those by A. mellifera did not. Because the visitation data used for this analysis include visits to male flowers, the numbers of visitations of A. mellifera might not directly reflect the number of visits to female flowers. In addition, we should be aware that the results of seed formation could also be related to the annual variations in the conditions of local climate or D. kaki trees (Charrier et al. 2015; Yamada et al. 1987). Still, it would be an important information that the abundant visits of A. mellifera in the orchard did not result in significant increase in seed formation, though further close experiments are needed to affirm the contributions of the two species for pollination.

Although we detected no positive relationship between visits by A. mellifera and seed formation, the result does not necessarily indicate that they cannot transport pollen to female flowers. Since not a few A. mellifera visited female flowers (Table 1) and their foraging behaviors there were generally similar to those of bumblebees (Fig. S3), A. mellifera would have an ability to deposit pollen onto the stigmas as B. ardens ardens do if they carry pollen. Negative behaviors, like removing pollen from stigmas, as reported by Gross and Mackay (1998), were not observed. As A. mellifera captured on female flowers of $D$. kaki had significantly fewer Diospyros pollen grains on their body surfaces than those captured on male ones, the presumably limited contribution of A. mellifera might be due to the limited crossvisitation between floral sexes.

Apis mellifera shows highly integrated and systematic division of labor in foraging for nectar or pollen (Free 1967; Ribbands 1949). If the nectar foragers overlook male flowers owing to the lack of nectar or any other reasons and the pollen foragers overlook female flowers owing to the lack of pollen, the opportunity to transfer pollen to female flowers would be rare. Yokozawa (1951) reported similar results for pollination of D. kaki by A. cerana japonica: only $4.1 \%$ of female-flower visitors had pollen loads on their hind legs, while $90.8 \%$ of male-flower visitors had them. Yokozawa 
(a)

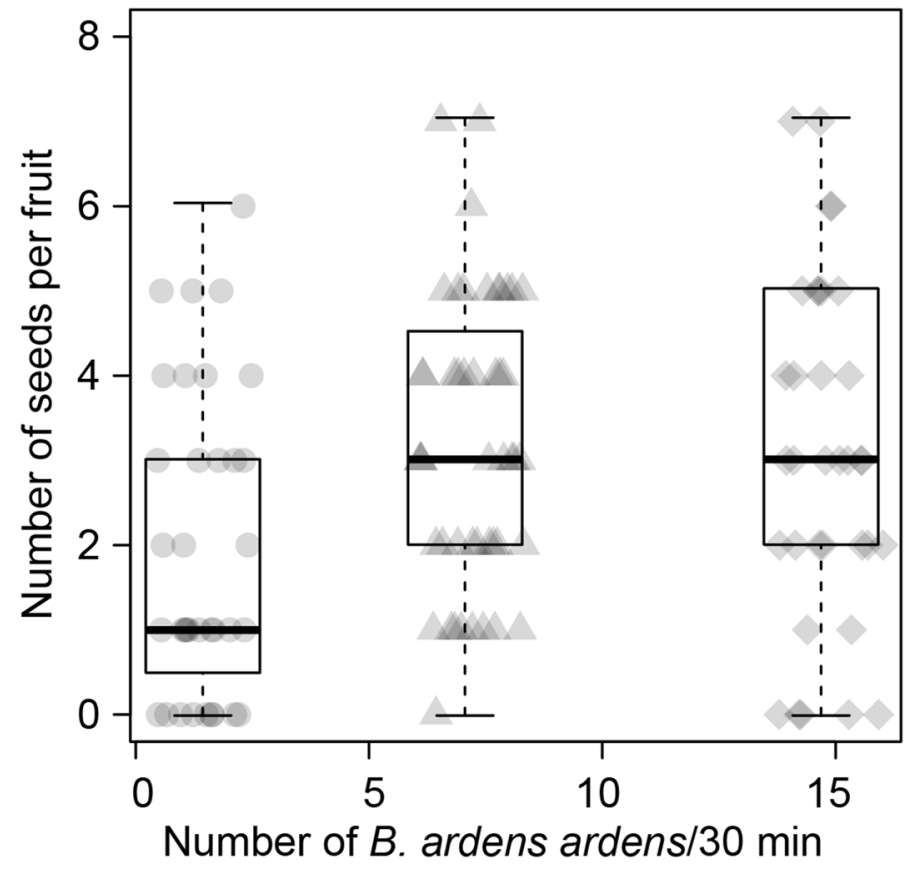

(b)

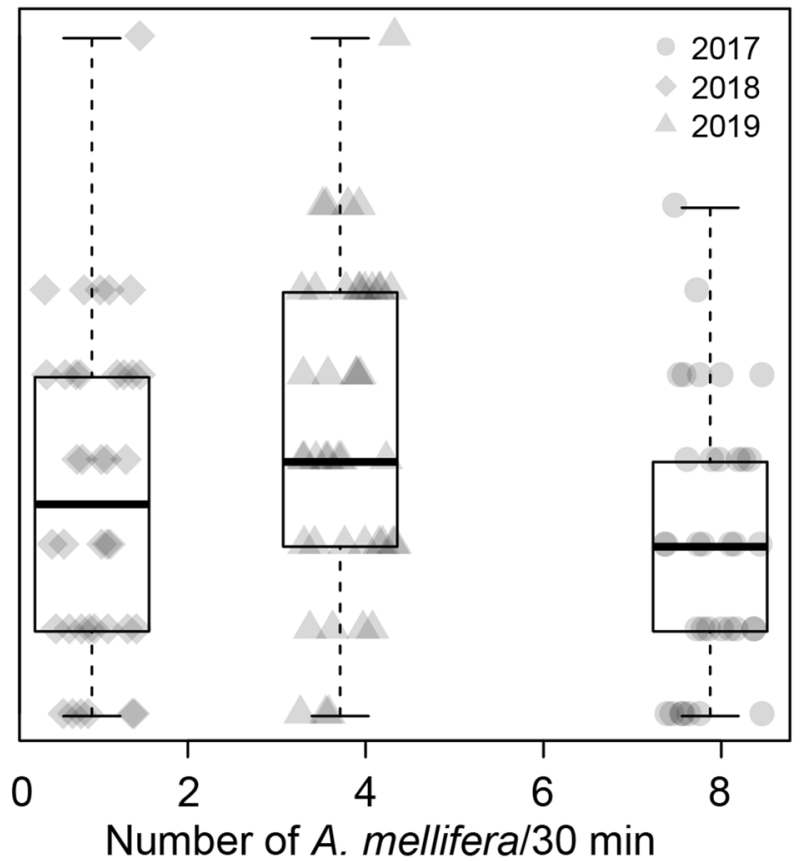

Fig. 2 Relationship between the number of observed visits by (a) Bombus ardens ardens or (b) Apis mellifera and the number of mature seeds per Diospyros kaki fruit. The numbers of visitations were standardized to $30 \mathrm{~min}$ observation in each year. The data used to plot this figure conform to the datasets used for the GLM analyses of the effects of the number of visitations by A. mellifera $(N=116)$

(1952) later confirmed that the workers of A. cerana japonica captured on female flowers had fewer pollen grains on the forewings than those captured on male flowers. Although these studies were performed on A. cerana japonica, not $A$. mellifera, both species show a similar division of labor in foraging nectar or pollen (Jhajj and Goyal 1979; Verma and Dulta 1986).

In contrast, B. ardens ardens carried many Diospyros pollen grains on their body surfaces regardless of the flower sexes they foraged, suggesting their frequent cross-visitations between male and female flowers. These flexible foraging patterns might result in abundant pollen deposition on female flowers and make them efficient pollinators of D. kaki, as shown by Nikkeshi et al. (2019). Konzmann and Lunau (2014) reported that Bombus terrestris (L.) (Hymenoptera: Apidae) did not specialize in nectar or pollen collection (but see Russell et al. 2017). Further studies should directly count and compare the frequency of cross-visitations between $A$. mellifera and $B$. ardens ardens in multiple locations to confirm the generality of this trend.

The positive contribution of $A$. mellifera, if any, might be undetectable or reversed by those of highly efficient $B$. ardens ardens. Because female-visiting $A$. mellifera carried only $0.3 \%$ of the numbers of pollen grains carried by or $B$. ardens ardens $(N=116)$ on the number of mature seeds. The top and bottom lines of the boxes indicate upper and lower quartiles, horizontal lines inside the boxes indicate median, and top and bottom ends of whiskers indicate 1.5-interquartile ranges (IQR) between lower (25th percentile-1.5.IQR) and upper (75th percentile $+1.5 \cdot \mathrm{IQR})$ values

$B$. ardens ardens on their body surfaces, and the visitation frequencies of $A$. mellifera and $B$. ardens ardens were negatively correlated with each other, the analysis for the visitation effects of $A$. mellifera might be affected by the hidden effects of $B$. ardens ardens. As $68 \%$ of homing A. mellifera carried at least a few Diospyros pollen grains on their body surfaces, multiple visitations by mass individuals could result in depositing enough pollen grains on stigmas for seed formation (Fukae et al. 1987; Morse 1991). Nevertheless, the contribution by introduced A. mellifera to the pollination of D. kaki might be limited in orchards where other effective wild pollinators are present.

Contrary to the report by Fukae et al. (1987), none of the 19 pollen-foraging A. mellifera returned with Diospyros pollen loads, suggesting that workers did not collect Diospyros pollen grains as an important pollen source in our study field. Although we found $5.2 \%$ of homing workers (five individuals) dusted with abundant (>10 000) Diospyros pollen on their body surfaces, which strongly indicated their visitation to Diospyros male flowers, they did not return with any pollen loads. This result suggests that they did not focus on collecting pollen on Diospyros flowers and that these visits would be quite occasional ones in expectation of nectar. Instead, the colony seemed to depend mainly on 
clovers (T. pratense and T. repens) and Toxicodendron for pollen. Although there were no large patches of $T$. pratense or T. repens within the orchard, A. mellifera often flies further from the hive to forage for highly rewarding flowers (Beekman and Ratnieks 2000). Trees of Toxicodendron succedaneum (L.) Kuntze (Sapindales: Anacardiaceae) naturally grew around the orchard. Floral choice by pollinators is often influenced by the availability of co-flowering species or coexisting potential competitors (Spiesman and Gratton 2016). Some studies reported that fruit trees and clovers compete with each other for pollinators (Clinch 1984; Holzschuh et al. 2012; MacRae et al. 2005; Yokozawa et al. 1968).

We observed that the visitations of A. mellifera to $D$. kaki highly fluctuated even between years when the same number of hives was placed. Since the activity of the hives seemed to be similar between years, the annual fluctuation in the numbers of the dominant wild pollinator, B. ardens ardens, might have partially affected the visitation of $\mathrm{A}$. mellifera (Wignall et al. 2020). Because availability of wild and domesticated pollinators and their effectiveness for crop production would vary depending on the local situation, accumulating the basic local information would be important for the more general understanding of the contribution of $A$. mellifera on the pollination of $D$. kaki in various conditions.

\section{Conclusion}

Formation of $D$. kaki seeds was not related to the high availability of A. mellifera, but to that of $B$. ardens ardens. Analysis of pollen grains on the body surfaces revealed that workers of A. mellifera would be less efficient than those of $B$. ardens ardens, maybe owing to their rare cross-visitation between floral sexes. Although these results might also be affected by the local environmental factors or annual variation in the condition of $D$. kaki trees, the contribution by the introduced A. mellifera to the pollination of $D$. kaki could be limited in orchards where other effective wild pollinators are present. Apis mellifera relied on co-flowering clovers and Toxicodendron spp. instead of D. kaki for pollen at our site. The frequency of cross-visitation, the number of pollen grains deposited by a single visit, and the effects of co-occurring flower and pollinator species should be all integrated in the planning of cost-effective A. mellifera introduction.

Acknowledgements We thank Ms. Satomi Kohara for her technical help. We are grateful to Dr. Hiromitsu Inoue (Institute of Fruit Tree and Tea Science, National Agriculture and Food Research Organization) for providing photographs and videos. This work was supported financially by the Ministry of Agriculture, Forestry and Fisheries, Japan, through a research project entitled 'Monitoring and enhancement of pollinators for crop production.'
Open Access This article is licensed under a Creative Commons Attribution 4.0 International License, which permits use, sharing, adaptation, distribution and reproduction in any medium or format, as long as you give appropriate credit to the original author(s) and the source, provide a link to the Creative Commons licence, and indicate if changes were made. The images or other third party material in this article are included in the article's Creative Commons licence, unless indicated otherwise in a credit line to the material. If material is not included in the article's Creative Commons licence and your intended use is not permitted by statutory regulation or exceeds the permitted use, you will need to obtain permission directly from the copyright holder. To view a copy of this licence, visit http://creativecommons.org/licenses/by/4.0/.

\section{References}

Asami Y, Chow CT (1936) Is the pollen of Japanese persimmons carried by wind? J Hort Assoc Japan 7:247-251. https://doi. org/10.2503/jjshs.7.247

Beekman M, Ratnieks FLW (2000) Long-range foraging by the honey-bee, Apis mellifera L. Funct Ecol 14:490-496. https:// doi.org/10.1046/j.1365-2435.2000.00443.x

Charrier G, Ngao J, Saudreau M, Ameglio T (2015) Effects of environmental factors and management practices on microclimate, winter physiology, and frost resistance in trees. Front Plant Sci 6:259. https://doi.org/10.3389/fpls.2015.00259

Clinch PG (1984) Kiwifruit pollination by honey bees. 1. Tauranga observations, 1978-81. New Zeal J Exp Agric 12:29-38. https ://doi.org/10.1080/03015521.1984.10427785

Folmer O, Black M, Hoeh W, Lutz R, Vrijenhoek R (1994) DNA primers for amplification of mitochondrial cytochrome c oxidase subunit I from diverse metazoan invertebrates. Mol Mar Biol Biotechnol 3:294-299. https://www.mbari.org/wp-content/ uploads/2016/01/Folmer_94MMBB.pdf

Françoso E, Arias MC (2013) Cytochrome c oxidase I primers for corbiculate bees: DNA barcode and mini-barcode. Mol Ecol Resour 13:844-850. https://doi.org/10.1111/1755-0998.12135

Free JB (1967) Factors determining the collection of pollen by honeybee foragers. Anim Behav 15:134-144. https://doi. org/10.1016/S0003-3472(67)80024-1

Fukae Y, Hamachi F, Tsujikawa Y (1987) A detailed analysis of the effect of honeybee introduction on the pollination of persimmons. Honeybee Science 8:167-171 (in Japanese with English abstract)

Gross CL, Mackay D (1998) Honeybees reduce fitness in the pioneer shrub Melastoma affine (Melastomataceae). Biol Conserv 86:169-178. https://doi.org/10.1016/S0006-3207(98)00010-X

Holzschuh A, Dudenhöffer JH, Tscharntke T (2012) Landscapes with wild bee habitats enhance pollination, fruit set and yield of sweet cherry. Biol Conserv 153:101-107. https://doi. org/10.1016/j.biocon.2012.04.032

Japanese Government Statistics (2016) The e-Stat (a portal site for Japanese Government Statistics) of the Statistics Bureau, Ministry of Internal Affairs and Communications. Table p00128-015 (In Japanese). https://www.e-stat.go.jp/stat-search/files ?page $=1 \&$ layout $=$ datalist $\&$ toukei $=00500503 \&$ tstat $=00000$ $1020907 \&$ cycle $=7 \&$ year $=20160 \&$ month $=0 \&$ tclass $1=00000$ $1032892 \&$ tclass $2=000001126975$. Accessed 31 October 2019

Jhaij HS, Goyal NP (1979) Comparative behaviour of pollen foragers of Apis cerana indica and Apis mellifera. J Apicult Res 18:279-284. https://doi.org/10.1080/00218839.1979.11099983

Kawagoe H, Inoue J (1958) Studies on the pollination in Japanese persimmon. II. On the time required for fertilization and increase efficiency in artificial pollination. Special Bull Okayama Agric Exp Sta 56:153-162 (in Japanese) 
Konzmann S, Lunau K (2014) Divergent rules for pollen and nectar foraging bumblebees-A laboratory study with artificial flowers offering diluted nectar substitute and pollen surrogate. PLoS ONE 9:e91900. https://doi.org/10.1371/journal.pone.0091900

Kumar S, Stecher G, Tamura K (2016) MEGA7: molecular evolutionary genetics analysis version 7.0 for bigger datasets. Mol Biol Evol 33:1870-1874. https://doi.org/10.1093/molbev/ msw054

MacRae AW, Mitchem WE, Monks DW, Parker ML (2005) White clover (Trifolium repens) control and flower head suppression in apple orchards. Weed Technol 19:219-223. https://doi. org/10.1614/WT-02-024

Morse RA (1991) Honeybees forever. Trends Ecol Evol 6:337-338. https://doi.org/10.1016/0169-5347(91)90043-W

Nikkeshi A, Inoue H, Arai T, Kishi S, Kamo T (2019) The bumblebee Bombus ardens ardens (Hymenoptera: Apidae) is the most important pollinator of Oriental persimmon, Diospyros kaki (Ericales: Ebenaceae), in Hiroshima, Japan. Appl Entomol Zool 54:409419. https://doi.org/10.1007/s13355-019-00637-x

Ono M (1956) On some volume increasing materials of pollen in fruit tree's hand pollination. Powders and plant pollen. Tech Bull Fac Hort Chiba Univ 4:39-55 (in Japanese with English abstract)

R Development Core Team (2019) R: A language and environment for statistical computing. R Foundation for Statistical Computing, Vienna, Austria. https://www.R-project.org. Accessed 28 November 2019

Ribbands CR (1949) The foraging method of individual honey-bees. J Anim Ecol 18:47-66. https://doi.org/10.2307/1581

Russell AL, Morrison SJ, Moschonas EH, Papaj DR (2017) Patterns of pollen and nectar foraging specialization by bumblebees over multiple timescales using RFID. Sci Rep 7:42448. https://doi. org/10.1038/srep42448

Sasaki M (2010) Bee's eye view of flowering plants: Nectar- and pollen-source plants and related honeybee products. Kaiyusha, Tokyo (in Japanese)

Simon C, Frati F, Beckenbach A, Crespi B, Liu H, Flook P (1994) Evolution, weighting, and phylogenetic utility of mitochondrial gene sequences and a compilation of conserved polymerase chain reaction primers. Ann Entomol Soc Am 87:651-701. https://doi. org/10.1093/aesa/87.6.651

Spiesman BJ, Gratton C (2016) Flexible foraging shapes the topology of plant-pollinator interaction networks. Ecology 97:1431-1441. https://doi.org/10.1890/15-1735.1

Taberlet P, Gielly L, Pautou G, Bouvet J (1991) Universal primers for amplification of three non-coding regions of chloroplast DNA. Plant Mol Biol 17:1105-1109. https://doi.org/10.1007/BF000 37152
Tamura K, Nei M (1993) Estimation of the number of nucleotide substitutions in the control region of mitochondrial DNA in humans and chimpanzees. Mol Biol Evol 10:512-526. https:// doi.org/10.1093/oxfordjournals.molbev.a040023

Tokunaga M, Sasakawa M, Akiyama J (1959) Studies on the insectvisitors on the flowers of fruit trees. Sci Rep Kyoto Pref Univ Agric 11:59-70 (in Japanese with English abstract)

Verma LR, Dulta PC (1986) Foraging behaviour of Apis cerana indica and Apis mellifera in pollinating apple flowers. J Apicult Res 25:197-201. https://doi.org/10.1080/00218839.1986.11100717

Wignall VR, Harry IC, Davies NL, Kenny SD, McMinn JK, Ratnieks FLW (2020) Seasonal variation in exploitative competition between honeybees and bumblebees. Oecologia 192:351-361. https://doi.org/10.1007/s00442-019-04576-w

Yamada M, Kurihara A, Sumi T (1987) Varietal differences in fruit bearing in Japanese persimmon (Diospyros kaki Thunb.) and their yearly fluctuations. J Japan Soc Hort Sci 56:293-299 (in Japanese with English abstract)

Yamamura H (1982) Effects of pollination and fertilization on fruit set in "Saijo" Japanese persimmon. Bull Fac Agr Shimane Univ 16:8-13 (in Japanese with English abstract)

Yamamura H, Matsui K, Matsumoto T (1989) Effects of gibberellins on fruit set and flower-bud formation in unpollinated persimmons (Diospyros kaki). Sci Hort 38:77-86. https://doi. org/10.1016/0304-4238(89)90022-8

Yokozawa Y (1951) Insect visitors on the flowers of Japanese persimmon. J Japan Soc Hort Sci 20:58-64. https://doi.org/10.2503/jjshs .20 .58 (in Japanese)

Yokozawa Y (1952) Insect visitors on the flowers of Japanese persimmon (the second part). J Japan Soc Hort Sci 21:25-28. https:// doi.org/10.2503/jjshs.21.25 (in Japanese with English abstract)

Yokozawa Y, Yasui A, Morimoto M (1968) Studies on the transport of pollen of Japanese persimmons and peaches by insects. 1 . The efficiency of honeybee colonies. Bull Nara Agric Exp Sta 2:1-9 (in Japanese with English abstract)

Yonemori K, Kameda K, Sugiura A (1992) Characteristics of sex expression in monoecious persimmons. J Japan Soc Hort Sci 61:303-310. https://doi.org/10.2503/jjshs.61.303 (in Japanese with English abstract)

Publisher's Note Springer Nature remains neutral with regard to jurisdictional claims in published maps and institutional affiliations. 